\title{
BEHAVIOR OF THE DIAMETRIC DISTRIBUTION OF ECOLOGICAL GROUPS IN A MIXED OMBROPHILOUS FOREST FRAGMENT
}

\author{
Thiago Wendling Gonçalves de Oliveira ${ }^{*}$ Rafael Schmitz ${ }^{1}$ Jorge Danilo Zea Camaño ${ }^{1}$ Ana Paula Dalla Corte ${ }^{1}$ \\ Carlos Roberto Sanquetta ${ }^{1}$
}

\begin{abstract}
${ }^{1}$ Federal University of Paraná, Graduate Program in Forestry, Curitiba, Paraná, Brazil -thiagowendling@yahoo.com.br*; rflschmitz@gmail.com; jdzeaca@gmail.com; anapaulacorte@gmail.com; carlossanqueta@gmail.com
\end{abstract}

Received for publication: 22/11/2017 - Accepted for publication: 03/04/2018

\begin{abstract}
The Mixed Ombrophilous Forest is one of the most threatened ecosystems in Brazil. It is thus necessary to understand its dynamics of growth over time so that sustainable use and conservation management strategies be proposed. The objective of this study is to evaluate the behavior of the diametric distribution of two pioneer and non-pioneer ecological groups in a fragment of Mixed Ombrophilous Forest considering four years of evaluations: from 2002 to 2017. Exponential, Gamma, Weber and Weibull 3P density probability functions were adjusted. The diametric behavior of the forest and the ecological groups analyzed remained negative exponentially, being a characteristic of natural forests. The distributions that best adjusted were Weibull 3P for the forest as a whole and for the group of pioneers, and Weber for non-pioneers. We concluded that ecological groups have the same pattern of diametric distribution as the forest as a whole. However, different forest management strategies are necessary considering the intrinsic characteristics of each group.
\end{abstract}

Keywords: Araucaria Forest, probability density functions, diameter classes.

\section{Resumo}

Comportamento da distribuição diamétrica de grupos ecológicos em um fragmento de Floresta Ombrófila Mista. A Floresta Ombrófila Mista é um dos ecossistemas mais ameaçados do Brasil. Assim, é necessário entendimento da sua dinâmica de crescimento ao longo do tempo para que estratégias de manejo de uso sustentável e conservação sejam propostas. O objetivo deste trabalho foi avaliar o comportamento da distribuição diamétrica de dois grupos ecológicos, pioneiras e não pioneiras, em um fragmento de Floresta Ombrófila Mista, considerando-se quatro anos de avaliações no período de 2002 a 2017. Foram ajustadas as funções de densidade de probabilidade Exponencial, Gama, Weber e Weibull 3P. O comportamento diamétrico da floresta e dos grupos ecológicos analisados manteve-se exponencial negativo, sendo uma característica própria de florestas naturais. As distribuições que melhor se ajustaram foram a Weibull 3P, para a floresta como um todo bem como para o grupo das pioneiras, e a Weber, para as não pioneiras. Conclui-se que os grupos ecológicos apresentam o mesmo padrão de distribuição diamétrica da floresta como um todo. Contudo, são necessárias diferentes estratégias de manejo florestal, considerando-se as características intrínsecas de cada grupo.

Palavras-chave: Floresta com Araucária, funções de densidade de probabilidade, classes de diâmetro.

\section{INTRODUCTION}

The Mixed Ombrophilous Forest (MOF) is a forest typology in the South and Southeastern regions of Brazil. It presents a great tree diversity distributed in different ecological groups. However, the MOF is currently highly fragmented and considered one of the most threatened ecosystems in the country (MARTINELLI; MORAES, 2013). Therefore, it is necessary to understand its growth dynamics so that management strategies, whether for sustainable use or conservation, can be proposed.

In this context, growth studies involving modeling diametric distribution, growth and dynamics of ecological groups of naturally occurring species are essential for a sustainable forest management. Such studies contribute to increase knowledge on the processes of entry and mortality of forests, such as the maintenance of commercially important species (MACIEL et al., 2003). Thus, diametric distribution analyses allow growth stocks and forest structure to be evaluated by ecological groups or by species (MACHADO et al., 2017), and it is necessary to use mathematical models capable of describing the behavior of the forest over evaluation years.

Currently, many mathematical models are used to describe the number of trees in certain diameter classes. Such models are known as probability density function; Weibull 3P and Gama are among the most used (NASCIMENTO et al. 2012; BINOTI et al., 2014; EBLING et al., 2014; TÉO et al., 2015; SCHIKOWSKI et al., 2016; CYSNEIROS et al., 2017). The evaluation of the performance of such diametric distribution functions is performed mainly by the Komolgorov-Smirnov adhesion test (ORELLANA et al., 2014; MACHADO et al., 2017).

FLORESTA, Curitiba, PR, v. 48, n.3, p. 413-424, jul/set. 2018

Oliveira. T.W.G. et.al.

ISSN eletrônico 1982-4688

DOI: 10.5380/rf.v48i3. 56466 
In the case of the Mixed Ombrophilous Forest, studies on its growth, including at a species level, are necessary to support management plans and public policies. In view of this, the knowledge on the diametric structure of the forest allows making inferences about the characteristics of ecological groups. Thus, it is possible to propose more adequate management strategies to assist in the growth of forest remnants and to allow a rational use of resources (LIMA; LEÃO, 2013).

In view of the above, the hypothesis of this study is that the diametrical distribution of each ecological group presents a different behavior from the forest as a whole. Aiming to answer this hypothesis and provide information that can be applied to a sustainable management of the forest, the objective of this study is to verify the behavior of the diametric distribution over time in a Mixed Ombrophilous Forest fragment by adjusting probabilistic distribution functions taking into account different ecological groups.

\section{MATERIALS AND METHODS}

The study area was a remnant of the Montana Mixed Ombrophilous Forest located in the municipality of General Carneiro, state of Paraná, Brazil. The climate of the region, according to the Köppen classification, is temperate with mild summers $(\mathrm{Cfb})$; average temperature of the warm month are lower than $22 \mathrm{C}$, rainfall reaches 2,000 mm, and there is frequent severe frosts (ALVARES et al., 2013). The main soils of the region are Neosols and Nitosols (EMBRAPA, 2008).

In 1999, four permanent plots with one hectare each were distributed randomly in the study area with annual remediation. For the evaluation, all individuals with a diameter at 1.3 meters high (Dap) equal to or greater than 10 $\mathrm{cm}$ were identified botanically at a species level (APG III, 2009), and the diameters were measured. The data used in this study are from the eight plots of forest inventories carried out in 2002, 2007, 2012 and 2017.

The different species identified in the forest remain were divided into two ecological groups according to their characteristics: Pioneers, which tolerate direct sunlight; and Non-Pioneers, which have a shadow tolerance (HENTZ et al., 2017; SWAINE; WHITMORE, 1988).

The definition of the number of classes and intervals of Dap classes for the forest as a whole and for the different ecological groups mentioned above was performed using the Sturges formula, which considers the total number of trees and the amplitude of Dap data.

$$
\begin{gathered}
n_{c}=1+3.322 * \log _{10}(n) \\
i_{c}=\frac{A}{n_{c}}
\end{gathered}
$$

In which: $n_{c}$ : number of classes; $i_{c}$ : interval of classes; $n$ : total number of trees; A: amplitude of Dap data.

For the calculation of the number and interval of classes, data for the forest as a whole were used in 2002. For subsequent years and for the different ecological groups, the amplitudes of classes defined for the same year were used.

Four probability density functions (Table 1) were adjusted to evaluate the behavior of the diametric distribution in different years for the forest as a whole, considering the species in their respective ecological groups (pioneer or non-pioneer). The value of $\mathrm{f}(\mathrm{x})$ represents the frequency calculated by each probability density function adjusted from a previously defined class center of the variable Dap (x) previously defined.

Table 1. Probability distribution functions used for estimating the frequencies of the diametrical distribution of a Mixed Ombrophilous Forest fragment.

Tabela 1. Funções de distribuição probabilística empregadas na estimativa das frequências da distribuição diamétrica para um fragmento de Floresta Ombrófila Mista.

\begin{tabular}{ccc}
$\begin{array}{c}\text { Probability density } \\
\text { function }\end{array}$ & Formulation & Parameters \\
\hline Exponential & $f_{(x)}=\frac{1}{\beta} e^{-\frac{x}{\beta}}$ & $\begin{array}{c}\beta=\text { parameter to be estimated by the } \\
\text { Exponential function; } e=\text { Euler constant. }\end{array}$ \\
\hline Gamma & $f_{(x)}=\frac{x^{\alpha-1} e^{-\frac{x}{\beta}}}{\beta^{\alpha} \Gamma(\alpha)}$ & $\begin{array}{l}\alpha, \beta=\text { parameters to be estimated by the } \\
\text { Gamma function; } \Gamma=\text { gamma function. }\end{array}$ \\
\hline $\begin{array}{c}\text { Weibull with three } \\
\text { parameters (3P) }\end{array}$ & $f_{(x)}=\left(\frac{c}{b}\right)\left(\frac{x-a}{b}\right)^{c-1} e\left[-\left(\frac{x-a}{b}\right)^{c}\right]$ & $\begin{array}{l}a=\text { location parameter; } b=\text { scale } \\
\text { parameter; } c=\text { shape parameter. }\end{array}$
\end{tabular}




Weber $\quad f_{(x)}=\frac{x^{a}}{(b+c x)^{d}} \quad a, b, c, d=$ parameters to be estimated by
the Weber function.

The distribution functions were adjusted using the Table Curve 2D v3 software. The KolmogorovSmirnov adhesion test was calculated after estimating the diametric frequencies by probability distribution functions, adopting a 95\% probability. The calculated value of the Kolmogorov-Smirnov test was compared with the table value, so that if $D_{c a l}<D_{t a b}$, it is accepted that the distribution function adheres to real frequency data of diametric classes.

$$
\begin{aligned}
& D_{c a l}= \frac{\max \left|F_{o b s}-F_{e s t}\right|}{n} \\
& D_{t a b}=\frac{1,36}{\sqrt{n}}
\end{aligned}
$$

In which: $\left(\mathrm{D}_{\text {cal }}\right)=$ calculated value of the Kolmogorov-Smirnov test; $\left(\mathrm{D}_{\text {tab }}\right)=$ tabulated value; $\max \left|F_{\text {obs }}-F_{\text {est }}\right|=$ maximum difference between the accumulated frequency observed and the estimated cumulative frequency; $n=$ total number of trees.

In a complementary way, a graphical analysis of the frequencies observed versus those estimated by the distribution of better performance for each ecological group in each evaluation year was performed, verifying the accuracy of the adjustment.

\section{RESULTS}

In the remnant of the Mixed Ombrophilous Forest of this study, the ecological groups totaled 3,795 individuals in 2017, 1,130 pioneer trees and 2,665 non-pioneer trees. The families of pioneers with the highest frequency were Asteracea, Euphorbiaceae and Myrsinaceae; the families Araucariaceae, Lauraceae and Aquifoliaceae were the most frequent in the non-pioneer group.

We observed that the group of pioneers had the lowest dispersion in relation to the mean Dap due to the smaller amplitude of the Dap over the four years of evaluation (Table 2). The highest Daps were from non-pioneer trees; the greater growth and longevity of individuals are characteristic of this ecological group.

Table 1. Descriptive statistics for the variable Dap $(\mathrm{cm})$ considering the forest as a whole and its classification according to the different ecological groups.

Tabela 2. Estatística descritiva para a variável Dap $(\mathrm{cm})$ considerando a floresta como um todo e sua classificação nos diferentes grupos ecológicos.

\begin{tabular}{|c|c|c|c|c|c|c|c|c|c|c|c|c|}
\hline \multirow{2}{*}{ Statistics } & \multicolumn{4}{|c|}{ Forest } & \multicolumn{4}{|c|}{ Pioneers } & \multicolumn{4}{|c|}{ Non-pioneers } \\
\hline & 2002 & 2007 & 2012 & 2017 & 2002 & 2007 & 2012 & 2017 & 2002 & 2007 & 2012 & 2017 \\
\hline Freq. & 3,114 & 3,356 & 3,689 & 3,795 & 810 & 914 & 1,071 & 1,130 & 2,304 & 2,442 & 2,618 & 2,665 \\
\hline Mean & 23.4 & 23.4 & 23.0 & 23.7 & 18.5 & 18.9 & 18.7 & 19.8 & 25.1 & 25.0 & 24.8 & 25.4 \\
\hline Median & 17.8 & 18.0 & 17.7 & 18.6 & 16.4 & 17.0 & 16.2 & 17.5 & 18.4 & 18.5 & 18.1 & 19.1 \\
\hline Mode & 10.8 & 10.5 & 10.8 & 11.8 & 10.5 & 10.5 & 11.8 & 11.8 & 10.8 & 12.7 & 10.8 & 12.1 \\
\hline Max dap & 175.1 & 177.9 & 182.4 & 129.6 & 54.1 & 55.1 & 57.0 & 59.8 & 175.1 & 177.9 & 182.4 & 129.6 \\
\hline Amp. & 165.1 & 167.9 & 172.8 & 121.3 & 44.1 & 45.1 & 47.0 & 51.5 & 165.1 & 167.9 & 172.8 & 121.3 \\
\hline Q1 & 13.2 & 13.2 & 13.1 & 13.6 & $12 . .8$ & 12.7 & 12.4 & 13.4 & 13.4 & 13.4 & 13.2 & 13.7 \\
\hline Q3 & 27.7 & 27.4 & 26.6 & 27.6 & 22.0 & 22.6 & 22.8 & 23.9 & 30.9 & 30.4 & 30.1 & 31.0 \\
\hline (Q3-Q1) & 14.5 & 14.1 & 13.5 & 14.0 & 9.2 & 9.9 & 10.3 & 10.6 & 17.5 & 17.0 & 16.9 & 17.3 \\
\hline $\mathrm{S}^{2}$ & 233.9 & 231.2 & 230.9 & 226.2 & 57.7 & 61.4 & 65.4 & 70.1 & 284.5 & 284.4 & 287.9 & 283.1 \\
\hline $\mathrm{S}$ & 15.3 & 15.2 & 15.2 & 15.0 & 7.6 & 7.8 & 8.1 & 8.4 & 16.9 & 16.9 & 17.0 & 16.8 \\
\hline CV $(\%)$ & 65.4 & 65.1 & 66.0 & 63.4 & 41.1 & 41.6 & 43.2 & 42.3 & 67.2 & 67.4 & 68.4 & 66.2 \\
\hline Assim. & 2.3 & 2.3 & 2.3 & 2.1 & 1.5 & 1.4 & 1.4 & 1.4 & 2.0 & 2.0 & 2.1 & 1.8 \\
\hline Kurtosis & 8.0 & 8.3 & 8.5 & 5.6 & 2.6 & 2.1 & 2.3 & 2.1 & 6.1 & 6.3 & 6.4 & 3.9 \\
\hline
\end{tabular}

Freq. = absolute frequency; Max dap = maximum diameter; Amp. = amplitude; Q1 = first quartile; $\mathrm{Q} 3$ = third quartile; (Q3-Q1) = interquartile dispersion; $\mathrm{S}^{2}=$ variance, $\mathrm{S}=$ standard deviation; $\mathrm{CV}=$ coefficient of variation $(\%)$; Assim. = asymmetry. 
Table 2 shows that the maximum Dap of the trees of the pioneer group did not exceed the value of $60.0 \mathrm{~cm}$ along the evaluation years. This indicates that this ecological group ceases growth from a certain diameter, entering the phase of senescence and probably death. A single tree presented a greater Dap in relation to the other trees for the forest as a whole and for the non-pioneer group in 2002, 2007 and 2012. However, in the inventory of 2017, it was possible to observe its death, which caused the decrease of the maximum Dap and, therefore, of the amplitude of data. However, the variance had less influence since only one observation was performed.

Interquartile dispersion analysis (Q3-Q1) revealed that 50\% of the Dap data evaluated for the forest as a whole is comprised within a range of $14.5,14.1,13.5$ and $14.0 \mathrm{~cm}$ for 2002, 2007, 2012 and 2017, respectively. The values of interquartile dispersion decreased for pioneers, since the Dap amplitude was lower for this group than for the non-pioneer group, showing that there is a greater degree of grouping of data.

The median and mean values for the four years of measurements were different for the forest as a whole and for the ecological groups, indicating that the diametric distribution is asymmetric. An increase in frequencies over the years was observed in all groups, which indicates that the rate of entry of trees is higher than the mortality rate. Over the evaluation years, the group of non-pioneers represented approximately $70 \%$ of the individuals in the forest.

The Sturges formula resulted in 14 classes of Dap, with a $13.92 \mathrm{~cm}$ interval between them. The relative frequencies observed for each class considering the forest as a whole and both ecological groups are presented in Table 3.

Table 3. Relative frequency by Dap class considering the forest as a whole and its classification in the different ecological groups.

Tabela 4. Frequência relativa por classe de Dap considerando a floresta como um todo e sua classificação nos diferentes grupos ecológicos.

\begin{tabular}{|c|c|c|c|c|c|c|c|c|c|c|c|c|c|}
\hline \multirow{3}{*}{$\begin{array}{l}\text { Class } \\
\text { number }\end{array}$} & \multirow{3}{*}{$\begin{array}{c}\text { Class } \\
\text { center } \\
(\mathrm{cm})\end{array}$} & \multicolumn{12}{|c|}{ Relative frequencies (\%) } \\
\hline & & \multicolumn{4}{|c|}{ Forest } & \multicolumn{4}{|c|}{ Pioneers } & \multicolumn{4}{|c|}{ Non-pioneers } \\
\hline & & 02 & 07 & 12 & 17 & 02 & 07 & 12 & 17 & 02 & 07 & 12 & 17 \\
\hline 1 & 16.5 & 67.1 & 67.3 & 67.6 & 65.7 & 80.0 & 76.7 & 75.8 & 72.9 & 62.5 & 63.8 & 64.3 & 62.7 \\
\hline 2 & 29.7 & 16.6 & 17.1 & 17.6 & 18.9 & 16.0 & 19.1 & 20.0 & 21.5 & 16.8 & 16.3 & 16.7 & 17.7 \\
\hline 3 & 42.9 & 8.6 & 7.9 & 7.1 & 7.3 & 3.7 & 3.8 & 3.6 & 4.9 & 10.3 & 9.4 & 8.5 & 8.3 \\
\hline 4 & 56.1 & 4.9 & 5.0 & 4.8 & 4.9 & 0.2 & 0.3 & 0.6 & 0.7 & 6.6 & 6.8 & 6.6 & 6.7 \\
\hline 5 & 69.3 & 1.9 & 1.8 & 1.9 & 2.1 & - & - & - & - & 2.6 & 2.4 & 2.6 & 3.0 \\
\hline 6 & 82.5 & 0.4 & 0.4 & 0.5 & 0.6 & - & - & - & - & 0.5 & 0.6 & 0.7 & 0.9 \\
\hline 7 & 95.7 & 0.3 & 0.3 & 0.3 & 0.3 & - & - & - & - & 0.4 & 0.4 & 0.4 & 0.4 \\
\hline 8 & 108.9 & 0.1 & 0.1 & - & - & - & - & - & - & 0.1 & 0.1 & - & - \\
\hline 9 & 122.1 & 0.1 & 0.1 & 0.1 & 0.1 & - & - & - & - & 0.1 & 0.2 & 0.2 & 0.2 \\
\hline 10 & 135.3 & - & - & - & - & - & - & - & - & - & - & - & - \\
\hline 11 & 148.5 & - & - & - & - & - & - & - & - & - & - & - & - \\
\hline 12 & 161.7 & - & - & - & - & - & - & - & - & - & - & - & - \\
\hline 13 & 174.9 & 0.03 & 0.03 & - & - & - & - & - & - & 0.04 & 0.04 & - & - \\
\hline \multirow[t]{2}{*}{14} & 188.0 & - & - & 0.03 & - & - & - & - & - & - & - & 0.04 & - \\
\hline & Total & 100.0 & 100.0 & 100.0 & 100.0 & 100.0 & 100.0 & 100.0 & 100.0 & 100.0 & 100.0 & 100.0 & 100.0 \\
\hline
\end{tabular}

More than $60 \%$ of the individuals were counted in the first Dap class (from 10.0 to $23.1 \mathrm{~cm}$ ) for the forest as a whole and in both ecological groups. The decrease in the relative frequency from the first to the second class of Dap was more pronounced in the pioneer group than in the non-pioneer group along the different evaluation years.

Pioneers present individuals up to the $4^{\text {th }}$ grade of Dap in the four years of evaluation, and only the nonpioneer group reached upper Dap classes, with individuals up to the $13^{\text {th }}$ and $14^{\text {th }}$ grades, but with some discontinuities. In general, more than $50 \%$ of the forest comprised of individuals in class 1 .

Regarding the adherence of the adjusted models to probability distribution functions and according to the results of the Kolmogorov-Smirnov test obtained for the different groups evaluated, the performance of Weibull $3 \mathrm{P}$ and Weber functions is highlighted in relation to the others (Table 4). 
Table 5. Kolmogorov-Smirnov test $\left(\mathrm{D}_{\text {cal }}\right)$ for distributions adjusted on different years for the forest as a whole and its classification in different ecological groups.

Tabela 6. Teste de Kolmogorov-Smirnov $\left(D_{\text {cal }}\right)$ para as distribuições ajustadas nos diferentes anos para a floresta como um todo e sua classificação nos diferentes grupos ecológicos.

\begin{tabular}{|c|c|c|c|c|c|c|c|c|}
\hline & \multicolumn{4}{|c|}{2002} & \multicolumn{4}{|c|}{2007} \\
\hline & Exp. & Gamma & Wb. 3P & Weber & Exp. & Gamma & Wb. 3P & Weber \\
\hline \multicolumn{9}{|c|}{ Forest } \\
\hline T N E & $1,722.7$ & $2,703.8$ & $3.177,8$ & $3.192,5$ & $1.854,7$ & $2.937,4$ & 3,412 & $3.419,4$ \\
\hline $\mathrm{D}_{\mathrm{tab}}$ & 0.0244 & 0.0244 & 0.0244 & 0.0244 & 0.0235 & 0.0235 & 0.0235 & 0.0235 \\
\hline $\mathrm{D}_{\mathrm{cal}}$ & 0.4502 & 0.1317 & $0.0205 *$ & 0.0252 & 0.4507 & 0.1247 & $0.0167 *$ & $0.0189 *$ \\
\hline Ranking & $4^{\text {th }}$ & $3^{\text {rd }}$ & $1^{\text {st }}$ & $2^{\text {nd }}$ & $4^{\text {th }}$ & $3^{\text {rd }}$ & $1^{\text {st }}$ & $2^{\text {nd }}$ \\
\hline \multicolumn{9}{|c|}{ Pioneers } \\
\hline T N E & 430.4 & 786.8 & 813.7 & 813.8 & 491.7 & 890.5 & 916.6 & 917.1 \\
\hline $\mathrm{D}_{\mathrm{tab}}$ & 0.0478 & 0.0478 & 0.0478 & 0.0478 & 0.045 & 0.045 & 0.045 & 0.045 \\
\hline $\mathrm{D}_{\mathrm{cal}}$ & 0.4782 & $0.0286 *$ & $0.0041 *$ & $0.0048 *$ & 0.5316 & $0.0258 *$ & $0.0029 *$ & $0.0034 *$ \\
\hline Ranking & $4^{\text {th }}$ & $3^{\text {rd }}$ & $1^{\text {st }}$ & $2^{\text {nd }}$ & $4^{\text {th }}$ & $3^{\text {rd }}$ & $1^{\text {st }}$ & $2^{\text {nd }}$ \\
\hline \multicolumn{9}{|c|}{ Non-pioneers } \\
\hline T N E & $1,300.6$ & $1,933.5$ & $2,373.4$ & $2,356.5$ & 1,368 & $2,055.7$ & $2,512.4$ & $2,493.6$ \\
\hline $\mathrm{D}_{\mathrm{tab}}$ & 0.0283 & 0.0283 & 0.0283 & 0.0283 & 0.0275 & 0.0275 & 0.0275 & 0.0275 \\
\hline $\mathrm{D}_{\mathrm{cal}}$ & 0.4376 & 0.1483 & $0.0176^{*}$ & $0.0240 *$ & 0.441 & 0.1582 & 0.0288 & $0.0263^{*}$ \\
\hline Ranking & $4^{\text {th }}$ & $3^{\text {rd }}$ & $1^{\text {st }}$ & $2^{\text {nd }}$ & $4^{\text {th }}$ & $3^{\text {rd }}$ & $2^{\text {nd }}$ & $1^{\text {st }}$ \\
\hline & \multicolumn{4}{|c|}{2012} & \multicolumn{4}{|c|}{2017} \\
\hline & Exp. & Gamma & Wb. 3P & Weber & Exp. & Gamma & Wb. 3P & Weber \\
\hline \multicolumn{9}{|c|}{ Forest } \\
\hline T N E & $2,035.6$ & $3,255.8$ & $3,729.8$ & $3,737.5$ & $2,112.3$ & $3,346.8$ & $3,827.6$ & $3,835.9$ \\
\hline $\mathrm{D}_{\mathrm{tab}}$ & 0.0224 & 0.0224 & 0.0224 & 0.0224 & 0.0221 & 0.0221 & 0.0221 & 0.0221 \\
\hline $\mathrm{D}_{\text {cal }}$ & 0.4509 & 0.1174 & $0.0111 *$ & $0.0131 *$ & 0.4462 & 0.1181 & $0.0086^{*}$ & $0.0108 *$ \\
\hline Ranking & $4^{\text {th }}$ & $3^{\text {rd }}$ & $1^{\text {st }}$ & $2^{\text {nd }}$ & $4^{\text {th }}$ & $3^{\text {rd }}$ & $1^{\mathrm{st}}$ & $2^{\text {nd }}$ \\
\hline \multicolumn{9}{|c|}{ Pioneers } \\
\hline T NE & 578 & $1,044.5$ & $1,071.7$ & $1,072.3$ & 616.9 & $1,092.6$ & $1,133.1$ & 1,134 \\
\hline $\mathrm{D}_{\text {tab. }}$ & 0.0416 & 0.0416 & 0.0416 & 0.0416 & 0.0405 & 0.0405 & 0.0405 & 0.0405 \\
\hline $\mathrm{D}_{\mathrm{cal}}$ & 0.5307 & $0.0248 *$ & $0.0006 *$ & $0.0012 *$ & 0.5152 & $0.0332 *$ & $0.0028 *$ & $0.0035 *$ \\
\hline Ranking & $4^{\text {th }}$ & $3^{\text {rd }}$ & $1^{\text {st }}$ & $2^{\text {nd }}$ & $4^{\text {th }}$ & $3^{\text {rd }}$ & $1^{\mathrm{st}}$ & $2^{\text {nd }}$ \\
\hline \multicolumn{9}{|c|}{ Non-pioneers } \\
\hline T N E & 1,462 & $2,218.4$ & $2,682.1$ & $2,668.1$ & $1,499.5$ & $2,259.6$ & $2,723.8$ & $2,716.1$ \\
\hline $\mathrm{D}_{\text {tab. }}$ & 0.0266 & 0.0266 & 0.0266 & 0.0266 & 0.0263 & 0.0263 & 0.0263 & 0.0263 \\
\hline $\mathrm{D}_{\text {cal }}$ & 0.4419 & 0.1526 & $0.0245^{*}$ & $0.0228 *$ & 0.4384 & 0.1521 & $0.0221 *$ & $0.0206 *$ \\
\hline Ranking & $4^{\text {th }}$ & $3^{\text {rd }}$ & $2^{\text {nd }}$ & $1^{\text {st }}$ & $4^{\text {th }}$ & $3^{\text {rd }}$ & $2^{\text {nd }}$ & $1^{\text {st }}$ \\
\hline
\end{tabular}

* adherence with $\mathrm{p}<0.05 ; \mathrm{T} \mathrm{N} \mathrm{E}=$ Total Number of individuals Estimated.

Considering the forest as a whole (Table 4), the Weibull 3P distribution presented the best fit since this function adhered in all years of evaluation by the Kolmogorov-Smirnov test. The second best function was Weber, whose adjustment indicated adherence from 2007.

In the pioneer group (Table 4), there was a similar behavior as that observed for the forest as a whole. The distributions Weibull $3 \mathrm{P}$ and Weber adhered to the frequencies observed on each evaluated year, being in $1^{\text {st }}$ and $2^{\text {nd }}$ in the ranking of distributions, respectively.

A different result was found for the group of non-pioneers (Table 4) since only the Weber distribution adhered over the years and presented the best performance for this group, occupying the first place in the ranking. The Weibull distribution also performed well $\left(2^{\text {nd }}\right)$, but did not show adhesion on 2007.

The exponential function did not adhere to any measurement year and provided the worst performances as observed in the estimated total frequencies (Table 4), which were well below the total frequency values observed for each group over the years (Table 2). The Gamma function only adhered to data observed for the pioneers. In the other groups, it did not perform well to represent the diameter distribution, underestimating the number of trees. 
The model that best represented the diametric distribution of the forest as a whole and the pioneers was the distribution of Weibull 3P. For the group of non-pioneers, it was the Weber distribution. Table 5 shows the respective adjustment parameters.

Table 5. Parameters for the Weibull 3P and Weber functions along different evaluation years for the forest as a whole and its classification in the different ecological groups.

Tabela 5. Parâmetros para as funções Weibull 3P e Weber nos diferentes anos de avaliação para a floresta como um todo e sua classificação nos diferentes grupos ecológicos.

\begin{tabular}{|c|c|c|c|c|c|}
\hline \multicolumn{2}{|c|}{ Pdf Parameters } & 2002 & 2007 & 2012 & 2017 \\
\hline \multicolumn{6}{|c|}{ Forest } \\
\hline \multirow{4}{*}{ Weibull 3P } & $\mathrm{a}$ & 12.5747 & 12.4370 & 12.2676 & 11.9715 \\
\hline & $\mathrm{b}$ & 10.4690 & 10.3025 & 10.1222 & 11.0854 \\
\hline & $\mathrm{c}$ & 0.6426 & 0.6641 & 0.6893 & 0.7360 \\
\hline & \multicolumn{5}{|c|}{ Pioneers } \\
\hline \multirow{3}{*}{ Weibull 3P } & $\mathrm{a}$ & 10.9784 & 10.0204 & 9.6725 & 9.8080 \\
\hline & $\mathrm{b}$ & 8.0987 & 10.0955 & 10.6802 & 11.2600 \\
\hline & $\mathrm{c}$ & 0.9729 & 1.14669 & 1.2100 & 1.1764 \\
\hline \multicolumn{6}{|c|}{ Non-pioneers } \\
\hline \multirow{4}{*}{ Weber } & $\mathrm{a}$ & -1.8976 & -2.0524 & -2.0682 & -1.8669 \\
\hline & $\mathrm{b}$ & 0.8832 & 0.8754 & 0.8798 & 0.8964 \\
\hline & $\mathrm{c}$ & 0.0004 & 0.0002 & 0.0002 & 0.0004 \\
\hline & $\mathrm{d}$ & 19.3397 & 21.1319 & 22.4050 & 21.4405 \\
\hline
\end{tabular}

Pdf: Probability distribution function.

Figure 1 and 2 show diametric distribution curves estimated by the Weibull 3P function in relation to the frequency histogram observed for the whole forest and for the pioneers in each diameter class in the different evaluation years, respectively. Figure 3 corresponds to the Weber distribution curves for the non-pioneer group.

By evaluating the curves shown in Figure 1, we can easily observe the adhesion of the Weibull 3P distribution in the forest as a whole, showing values very close to the frequencies observed by Dap class and showing flexibility in the changes in forest behavior over the years. A similar behavior can be observed with the Weibull 3P function for the pioneer group (Figure 2) and with the Weber function for the non-pioneer group (Figure 3).

According to Figure 1, the forest under study shows an inverted $\mathbf{J}$ behavior for its diametric distribution over the evaluated years. It should be noted that this pattern is kept for each pioneer and non-pioneer groups when analyzed separately. 

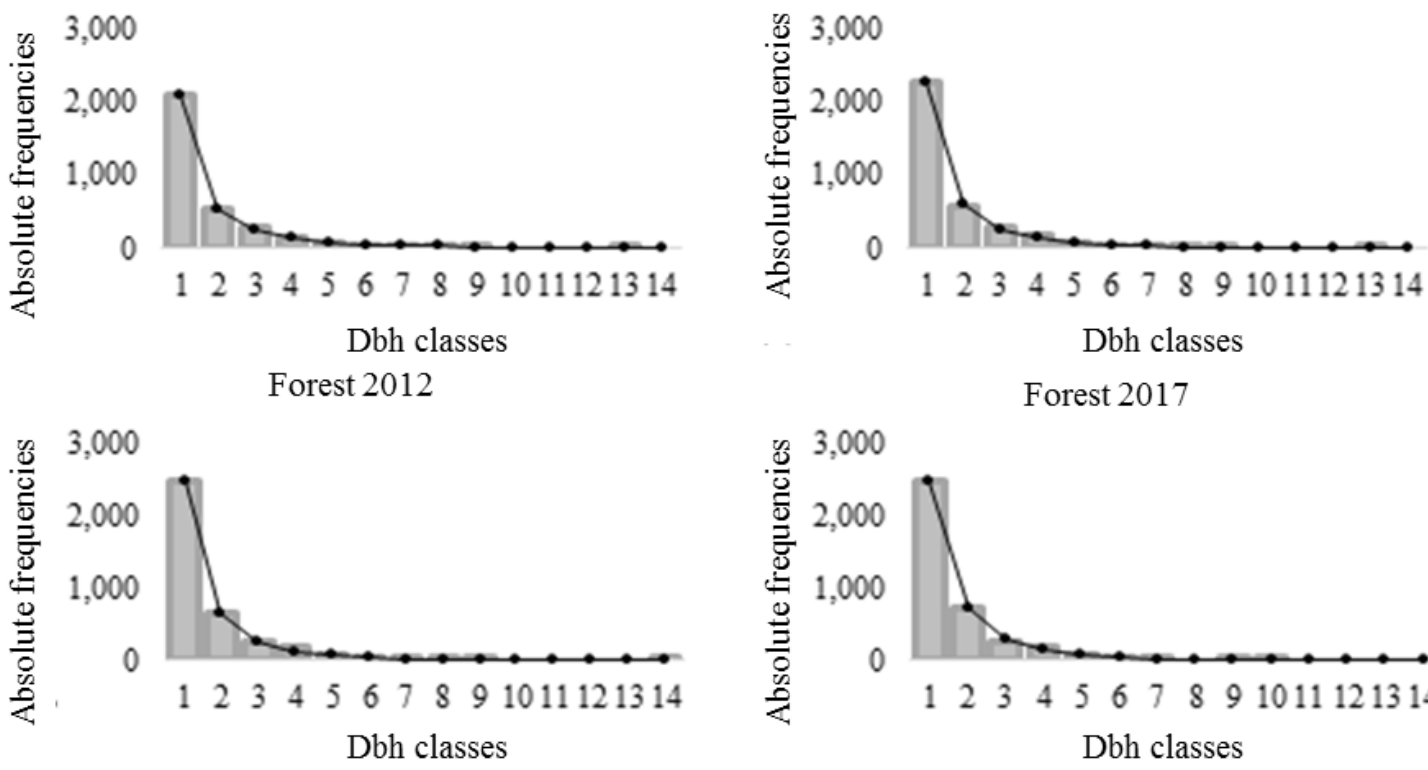

Forest 2017

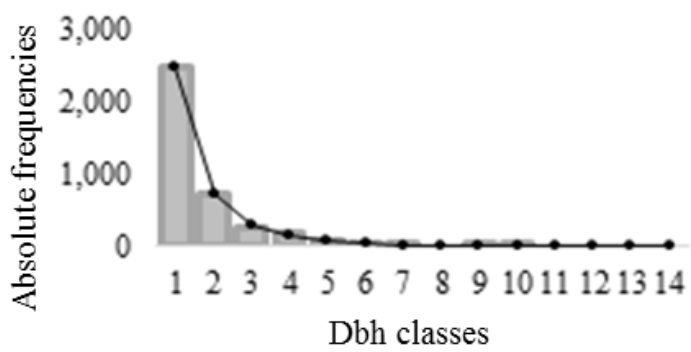

Observed Freq. $\rightarrow$ Weibull $3 P$

Figure 1. Weibull 3P distribution curves for the whole forest on different measurement years. Axis $\mathrm{X}=1$ (9.9 |-$23.1 \mathrm{~cm}) ; 2$ (23.1 |-- $36.3 \mathrm{~cm}) ; 3(36.3 \mid--49.5 \mathrm{~cm}) ; 4(49.5 \mid--62.7 \mathrm{~cm}) ; 5(62.7 \mid--75.9 \mathrm{~cm}) ; 6(75.9 \mathrm{~cm} \mid-$ - $89.1 \mathrm{~cm}) ; 7$ (89.1 cm |-- $102.3 \mathrm{~cm}) ; 8$ (102.3 |-- $115.5 \mathrm{~cm}) ; 9$ (115.5 |-- $128.7 \mathrm{~cm}) ; 10$ (128.7 |-- 141.9 cm); 11 (141.9 cm |-- $155.1 \mathrm{~cm}) ; 12(155.1 \mid--168.3 \mathrm{~cm}) ; 13(168.3 \mid--181.5 \mathrm{~cm}) ; 14(181.5 \mathrm{~cm} \mid--)$.

Figura 2. Curvas da distribuição de Weibull 3P para toda floresta nos diferentes anos de medição. Eixo $\mathrm{X}=1(9,9$ |-- 23,1cm); 2 (23,1 |-- 36,3cm); 3 (36,3 |-- 49,5cm); 4 (49,5 |-- 62,7cm); 5 (62,7 |-- 75,9cm); 6 (75,9|-$89,1 \mathrm{~cm}) ; 7$ (89,1 |-- 102,3cm); 8 (102,3 |-- 115,5cm); 9 (115,5 |-- 128,7cm); 10 (128,7 |-- 141,9cm); 11 (141,9|-- 155,1cm); 12 (155,1 |-- 168,3cm); 13 (168,3 |-- 181,5 cm); $14(181,5 \mathrm{~cm} \mid--)$.
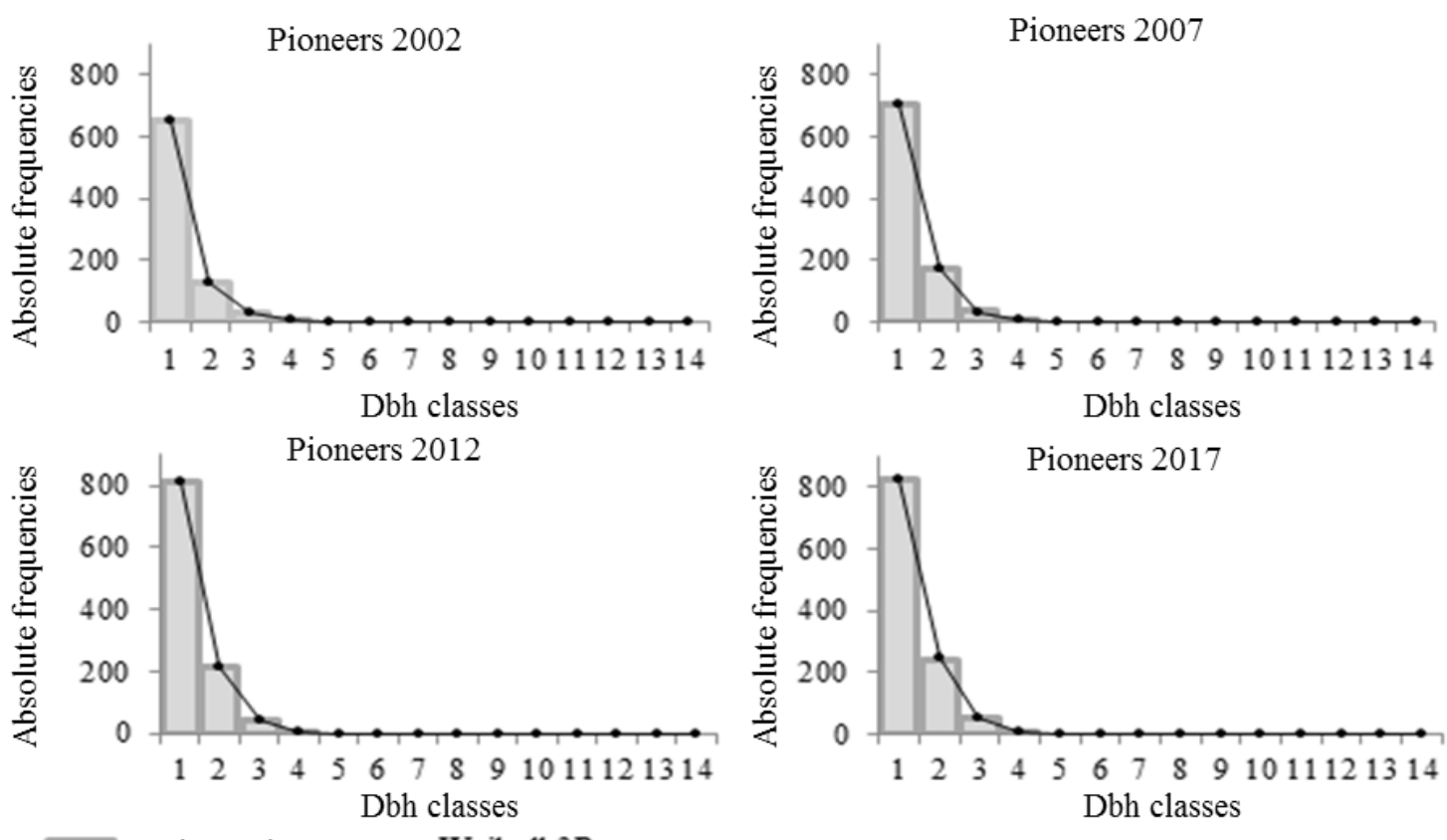

FLORESTA, Curitiba, PR, v. 48, n.3, p. 413-424, jul/set. 2018 
Figure 3. Weibull 3P distribution curves for the pioneers on different measurement years. Axis $\mathrm{X}=1$ (9.9 |-- 23.1 cm); 2 (23.1 |-- $36.3 \mathrm{~cm}) ; 3$ (36.3 |-- $49.5 \mathrm{~cm}) ; 4$ (49.5 |-- $62.7 \mathrm{~cm}) ; 5$ (62.7|-- $75.9 \mathrm{~cm}) ; 6$ (75.9 cm |-- 89.1 cm); 7 (89.1 cm |-- $102.3 \mathrm{~cm}) ; 8$ (102.3 |-- $115.5 \mathrm{~cm}) ; 9$ (115.5 |-- $128.7 \mathrm{~cm}) ; 10$ (128.7 |-- $141.9 \mathrm{~cm}) ; 11$ $(141.9 \mathrm{~cm} \mid--155.1 \mathrm{~cm}) ; 12(155.1 \mid--168.3 \mathrm{~cm}) ; 13(168.3 \mid--181.5 \mathrm{~cm}) ; 14(181.5 \mathrm{~cm} \mid--)$.

Figura 4. Curvas da distribuição de Weibull 3P para as pioneiras nos diferentes anos de medição. Eixo $\mathrm{X}=1$ ( 9,9 |-- 23,1cm); 2 (23,1 |-- 36,3cm); 3 (36,3 |-- 49,5cm); 4 (49,5 |-- 62,7cm); 5 (62,7 |-- 75,9cm); 6 (75,9|-$89,1 \mathrm{~cm}) ; 7$ (89,1 |-- 102,3cm); 8 (102,3 |-- 115,5cm); 9 (115,5 |-- 128,7cm); 10 (128,7|-- 141,9cm); 11 $(141,9 \mid--155,1 \mathrm{~cm}) ; 12(155,1 \mid--168,3 \mathrm{~cm}) ; 13(168,3 \mid--181,5 \mathrm{~cm}) ; 14(181,5 \mathrm{~cm} \mid--)$.
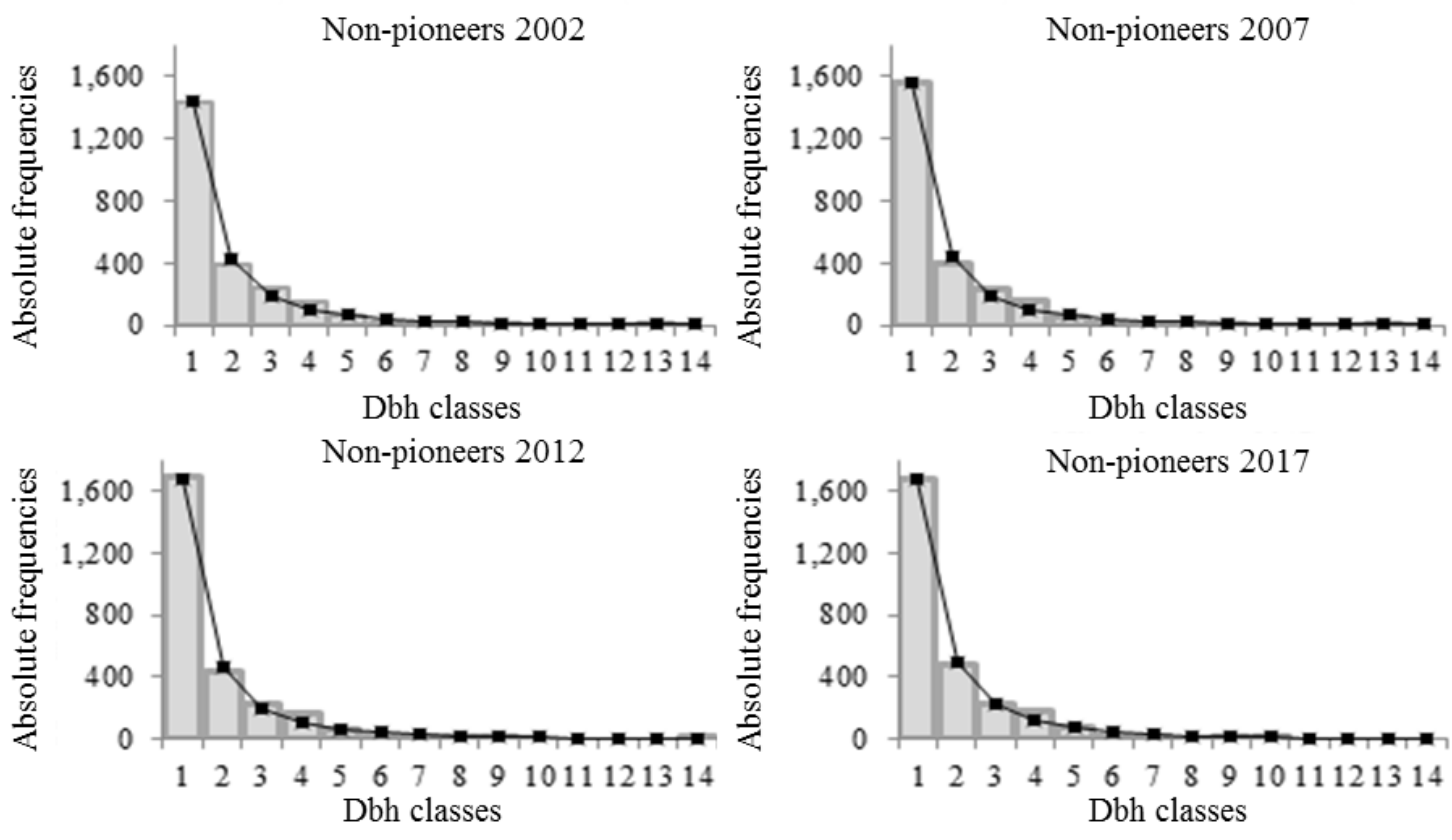

Figure 5. Weber distribution curves for the non-pioneers on different measurement years. Axis $X=1(9.9 \mid-23.1$ cm); 2 (23.1 |-- $36.3 \mathrm{~cm}) ; 3$ (36.3 |-- $49.5 \mathrm{~cm}) ; 4(49.5 \mid--62.7 \mathrm{~cm}) ; 5(62.7 \mid--75.9 \mathrm{~cm}) ; 6(75.9 \mathrm{~cm} \mid--89.1$ cm); 7 (89.1 cm |-- $102.3 \mathrm{~cm}) ; 8$ (102.3 |-- $115.5 \mathrm{~cm}) ; 9$ (115.5 |-- $128.7 \mathrm{~cm}) ; 10$ (128.7 |-- $141.9 \mathrm{~cm}) ; 11$ $(141.9 \mathrm{~cm} \mid--155.1 \mathrm{~cm}) ; 12(155.1 \mid--168.3 \mathrm{~cm}) ; 13(168.3 \mid--181.5 \mathrm{~cm}) ; 14(181.5 \mathrm{~cm} \mid--)$.

Figura 6. Curvas da distribuição de Weber para as não-pioneiras nos diferentes anos de medição. Eixo X=1 9,9 |-- 23,1 cm); 2 (23,1 |-- 36,3cm); 3 (36,3 |-- 49,5cm); 4 (49,5 |-- 62,7cm); 5 (62,7 |-- 75,9cm); 6 (75,9|-$89,1 \mathrm{~cm}) ; 7$ (89,1 |-- 102,3cm); 8 (102,3 |-- 115,5cm); 9 (115,5|-- 128,7cm); 10 (128,7|-- 141,9cm); 11 (141,9|-- 155,1cm); $12(155,1 \mid--168,3 \mathrm{~cm}) ; 13(168,3 \mid--181,5 \mathrm{~cm}) ; 14(181,5 \mathrm{~cm} \mid--)$.

\section{DISCUSSION}

The "inverted J" behavior, characteristic of the diametric distribution of the forest under study, has also been reported in other studies on native forests. For example, the studies by Figueiredo Filho et al. (2010), Longhi et al. (2017) and Machado et al. (2017), who worked with permanent plots in a Mixed Ombrophilous Forest in southern Brazil, Cysneiros et al. (2017), who studied a remnant of Dense Ombrophilous Forest in Rio do Janeiro, and studies by Santos et al. (2016), who worked with terra firme moist rainforest in the Amazon.

The fact that pioneer and non-pioneer ecological groups present an "inverted J" distribution seems to be a feature of the Mixed Ombrophilous Forest. Machado et al. (2017), for example, when studying this same type of forest and dividing it into ecological groups, found a similar behavior, with a higher concentration of individuals in the lower classes and a progressive reduction of the frequency in the subsequent classes. Schaaf et al. (2006), upon analyzing a group of Mixed Ombrophilous Forest species, stated that the "inverted J" distribution was a result of intrinsic characteristics of each species and ecological characteristics such as limit size, longevity, growth and competition among individuals. In this sense, the pioneers only developed up to the $4^{\text {th }}$ grade of Dap in the four 
years of evaluation, but the group of non-pioneers reached higher Dap classes due to the higher growth and longevity characteristics of this group.

The "inverted J" diametric behavior is a typical pattern of forests at an advanced state of natural regeneration (BLANC et al., 2000). Therefore, when considering that the group of non-pioneers represented approximately $70 \%$ of the individuals in the forest studied (Table 1) (CONAMA, 2007), it was possible to signal an advanced stage of succession for the tree population under analysis.

To define the management of a native forest, it is necessary to have a precise knowledge of its growth (LONGHI et al., 2017). In this sense, the information presented in this study allows the establishment of different sustainable management strategies for the forest since different ecological groups have different characteristics according to the maximum Dap, data amplitude, longevity of individuals, possibilities of use, conservation of endangered species, and use of timber and non-timber products.

Regarding probability distribution functions, the model that best adjusted for the entire forest and for the group of pioneers was the Weibull 3P distribution. This distribution was also the best for the study of Machado et al. (2009) on different species of a Mixed Ombrophilous Forest. According to Nascimento et al. (2012), the Weibull distribution model has mathematical tools that make it highly flexible. The different values of their coefficients allow the function to present different forms and asymmetries, adjusting to different forest typologies. These characteristics make it one of the most used functions for diametric distribution models (CURTO et al. 2014).

For the group of non-pioneers, the best distribution was the Weber function, a recent model for diametric distribution estimates. Therefore, even though it is not yet widely used for forest dynamics works, it has been adherent to the data set, presenting values close to those observed both in this study and in others where it was already used (MACHADO et al. 2009; CURTO et al. 2014). In their work, Machado et al. (2009) reported that the performance of the Weber function was similar to that of the Weibull 3P function. However, having a greater number of parameters allows this function to be more flexible in certain cases, as has been demonstrated for the group of non-pioneers.

Although the behavior of the diametric distribution of the forest as a whole and of different ecological groups is a negative exponential, the Exponential probabilistic function did not perform well and resulted in less flexibility. This may be related to the fact that it has only one adjustment parameter.

According to the results, there is not a single distribution function that best fitted the different groups evaluated in the remnant of Mixed Ombrophilous Forest. This feature has also been demonstrated for other remnants of Mixed Ombrophilous Forests, including species-level diametric distribution assessments (TÉO et al., 2015; SCHIKOWSKI et al., 2016).

By observing the best performances of probability density functions, it was possible to indicate that there is difference in the diametric behavior of the forest when working with different ecological groups. Thus, for example, it can be observed that pioneers present a greater decrease in observed and estimated frequencies (Table 3, Figure 2) than in the non-pioneer group (Table 3, Figure 3).

In contrast, the differences in frequencies observed for different Dap classes for the groups evaluated (Table 1, Figures 1, 2 and 3) did not cause behavioral changes that would disqualify the negative exponential representation characteristic of natural forests. In a study on a Mixed Ombrophilous Forest, it was demonstrated that, after a selective cut of light intensity (20-30\% reduction of the basal area), the forests still kept the "inverted $\mathrm{J}$ " behavior in their diametric distribution (LONGHI et al., 2017).

\section{CONCLUSIONS}

- The classification by ecological groups, pioneer and non-pioneer, in remnants of Mixed Ombrophilous Forest maintains the same pattern of diametric distribution of the forest as a whole ("inverted J" type).

- Although the ecological groups present the same pattern of diametric distribution, different strategies of forest management are necessary considering the characteristics intrinsic to pioneers and non-pioneers in relation to their growth and mortality.

- The decrease in the number of individuals from the first to the second class is greater in the group of pioneers than when we consider the forest as a whole and non-pioneers. This is an indication that this group has a different behavior regarding longevity and tree growth.

- The Weibull 3P function best represented the diametric distribution of the forest as a whole and pioneer groups. Weber's function better adjusted to the non-pioneer group. 


\section{REFERENCES}

ALVARES, C. A.; STAPE, J. L.; SENTELHAS, P. C.; GONÇALVES, J. L.de M.; SPAROVEK, G. Köppen's climate classification map for Brazil. Meteorologische Zeitschrift, Germany, v. 22, n. 6, p. 711-728, 2013.

ANGIOSPERM PHYLOGENY GROUP. An update of the Angiosperm Phylogeny Group classification for the orders and families of flowering plants: APG III. Botanical Journal of the Linnean Society, London, v. 161, n. 2, p. 105-121, 2009.

BINOTI, D. H. B.; BINOTI, M. L. M. da S.; LEITE, H. G.; CORDEIRO, M. A.; SANTOS, S. C. Funções densidade de probabilidade para descrição da distribuição diamétrica de povoamentos de Acacia mangium. Revista Brasileira de Ciências Agrárias, Belém, v.9, n.4, p. 583-589, 2014.

BLANC, L.; MAURY-LECHON, G.; PASCAL, J. P. Structure, floristic composition and natural regeneration in the forests of Cat Tien National Park, Vietnam: an analysis of the successional trends. Journal of Biogeography, Wiley, v. 27, p. 141-157, 2000.

CONAMA. Resolução n⿳0 388, de 23 de fevereiro de 2007, Publicada no DOU ${ }^{\circ}$ 38, de 26 de fevereiro de 2007, Seção 1, página 63.

CURTO, R.A.; MATTOS, P.P.; BRAZ, E.M.; ZACHOW, R.; NETTO, S.P. Caracterização da estrutura e desenvolvimento de modelos para quantificação do potencial madeireiro em povoamento não manejado de Araucaria angustifolia. Pesquisa Florestal Brasileira, Colombo, v. 34, n. 80, p. 303-319, 2014.

CYSNEIROS, V.C.; AMORIM, T.A.; MENDONÇA JUNIOR, J.O.; GAUI, T.D.; MORAES, J.C.R.; BRAZ, D.M.; MACHADO, S.A. Distribuição diamétrica de espécies da Floresta Ombrófila Densa no Sul do Estado do Rio de Janeiro. Pesquisa Florestal Brasileira, Colombo, v. 37, n. 89, p. 1-10, 2017.

EBLING, A.A.; PELISSARI, A.L.; ABRÃO, S.F.; BAMBERG, R. Prognose da estrutura diamétrica de remanescente de floresta com Araucária utilizando a função densidade de probabilidade Weibull. Revista Agro@mbiente On-line, Roraima, v. 8, n. 1, p. 112-118, 2014.

EMPRESA BRASILEIRA DE PESQUISA AGROPECUARIA (EMBRAPA). Mapa de solos do estado do Paraná: legenda atualizada. Rio de Janeiro: EMBRAPA, 2008. 74 p.

FIGUEIREDO FILHO, A.; DIAS, A.N.; STEPKA, T.F.; SAWCZUK, A.R. Crescimento, mortalidade, ingresso e distribuição diamétrica em Floresta Ombrófila Mista. Revista Floresta, Curitiba, v. 40, n. 4, 2010.

HENTZ, Â. M. K.: DALLA CORTE, A. P.; SANQUETTA, C. R.; BLUM, C. T.; CADORI, G. C. Edge effect on a tree community in an araucaria forest fragment in Brazil. Revista Floresta, Curitiba, v. 47, n.4, p.407-416, 2017.

LIMA, J.P. da C.; LEÃO, J.R.A. Dinâmica de crescimento e distribuição diamétrica de fragmentos de florestas nativa e plantada na Amazônia sul ocidental. Revista Floresta e Ambiente, Seropédica, v. 20, n.1, p. 70-79, 2013.

LONGHI, R. V.; SCHNEIDER, P. R.; DE SOUZA, D. F. L.; DOS SANTOS, G. L. Projeção da distribuição diamétrica em floresta com araucária explorada seletivamente no Sul do Brasil. Revista Brasileira de Ciências Agrárias, Belém, v. 12, n2, p. 210-219, 2017.

MACHADO, S.A.; AUGUSTYNCZIK, A.L.D.; NASCIMENTO, R.G.M.; TÉO, S.J.; MIGUEL, E.P.; FIGURA, M.A.; SILVA, L.C.R. Funções de distribuição diamétrica em um fragmento de Floresta Ombrófila Mista. Ciência Rural, Santa Maria, v. 39, n. 8, 2009.

MACHADO, S.A.; CYSNEIROS, V.; NASCIMENTO, R.G.; MARTINS, A. SCHMIDT, L. Projeção da estrutura diamétrica de grupos ecológicos em uma Floresta Ombrófila Mista. Revista Floresta e Ambiente, Seropédica, v.24, p.1-10, 2017.

MACIEL, M.N.M.; WATZLAWICK, L.F.; SCHOENINGER, E.R.; YAMAJI, F.M. Classificação ecológica de espécies arbóreas. Revista Acadêmica: ciências agrárias e ambientais. Curitiba, v.1, n.2, p.69-78, 2003.

MARTINELLI, G.; MORAES, M. A. Livro vermelho da flora do Brasil. Rio de Janeiro: Instituto de Pesquisas Jardim Botânico do Rio de Janeiro, 2013. 1100 p.

NASCIMENTO, R.G.M.; MACHADO, S.A.; FIGUEIREDO FILHO, A.; HIGUCHI, N. Modelo de projeção por classe diamétrica para florestas nativas: enfoque na função probabilística de Weibull. Pesquisa Florestal Brasileira, Colombo, v. 32, n. 70, p. 209, 2012. 
ORELLANA, E.; FIGUEIREDO FILHO, A.; NETTO, S.P.; DIAS, A.N. Modelagem da distribuição diamétrica de espécies florestais em um fragmento de floresta ombrófila mista. Revista Árvore, Curitiba, v. 38, n. 2, 2014.

SANTOS, R. O.; ABREU, J. C.; LIMA, R. B.; APARÍCIO, P. S.; SOTTA, E. D.; LIMA, R. C. Distribuição diamétrica de uma comunidade arbórea na Floresta Estadual do Amapá, Brasil. Biota Amazônia, Amapá, v. 6, n. 2, p. 24-31, 2016.

SCHAAF, L.B; FIGUEIREDO FILHO A.; GALVÃO F.; SANQUETTA C. R. Alteração na estrutura diamétrica de uma floresta ombrófila mista no período entre 1979 e 2000. Revista Árvore, Viçosa, v.30, n.2, p.283-295, 2006.

SCHIKOWSKI, A. B.; MARTINS, A. P. M.; SCHIAVO, B. N. V.; STANG, M. B.; CORTE, A. P. D., NETTO, S. P.; SANQUETTA, C. R. Dinâmica da distribuição diamétrica de Araucária angustifolia em um remanescente de Floresta Ombrófila Mista no Paraná. Rev. Bras. Biom, São Paulo, v.34, n.1, p.163-182, 2016.

SWAINE M.D.; WHITMORE T.C. On the definition of ecological species groups in tropical rain forests. Vegetation, Wiley, v. 75, p.81-86, 1988.

TÉO, S.J.; MARCON, F.; SCHNEIDER, C.R.; SANTOS, F.B. dos; CHIARELLO, K.M.A.; FIORENTIN, L.D. Modelagem da distribuição diamétrica de um fragmento de Floresta Ombrófila Mista em Lebon Régis, SC. Revista Floresta, v. 45, n. 2, p. 337-348, 2015. 
FLORESTA, Curitiba, PR, v. 48, n. 3, p. 413-424, jul/set.2018

Oliveira. T.W.G. et.al. 